\title{
Analisis budaya dan hambatan organisasi pada Bank " $X$ " di Bandung
}

\author{
Meidila Anggita* \\ Universitas Katolik Parahyangan \\ Jl. Ciumbuleuit 94. Bandung. 40141. Indonesia \\ meidila.anggita@gmail.com \\ *Penulis Korespondensi
}

Submitted: Mei 21, 2018; Reviewed: Jul 5, 2018; Accepted: Jul 26, 2018

\begin{abstract}
Culture and blockage is one of the important elements in company life, because it can make a significant contribution to the success or failure of an organization. The model used to assess the organizational culture is the Organizational Culture Assessment Instrument (OCAI) by Cameron \& Quinn. This model has four cultural types (clan, adhocracy, market, and hierarchy) and of the four cultural has 6 dimensions (dominant characteristic, organizational leadership, management of employee, organizational glue, strategic emphases, and criteria for success. Organizational blockage style is using Unblocking Organizational Questionnaire (UOQ) by Francis \& Woodcock. This model has 14 blockages in organization (unclear aims, unclear values, inappropriate management philosophy, lack of management development, confused organizational structure, inadequate control, inadequate recruitment and selection, unfair rewards, poor training, lack of personal development, inadequate communication, poor teamwork, low motivation, and low creativity). In collecting the data, the sample used is 28 people by distributing questionnaires. The results of this study it was found that Bank " $X$ ", adopted adhocracy cultural. However, for the next five years they are expected to have a combination of different cultures namely market and clan culture. Market cultural dimensions will be the main focus in the next five years to improve target achievement. This cultural profile picture can be use as input for corporate to policy making to create organizational culture that compatible with the corporate's vision dan mission. And for the result of blockage organization in the utilization of Human Resources in Bank $" X "$ are poor trainning, unfair rewards and low creativity.
\end{abstract}

Keywords: Organizational Blockage; Organization Culture; Organization Culture Assesment Instrument (OCAI); Unblocking Organizational Questionnaire (UOQ)

Abstrak: Budaya dan hambatan adalah salah satu elemen penting dalam kehidupan perusahaan, karena dapat memberikan kontribusi yang signifikan terhadap keberhasilan atau kegagalan organisasi. Model yang digunakan untuk menilai budaya organisasi adalah Instrumen Penilaian Budaya Organisasi (OCAI) oleh Cameron \& Quinn. Model ini memiliki empat jenis budaya (klan, adhokrasi, pasar, dan hierarki) dan empat budaya tersebut memiliki 6 dimensi (karakteristik dominan, kepemimpinan organisasi, manajemen karyawan, perekat organisasi, penekanan strategis, dan kriteria keberhasilan). Gaya hambatan organisasi menggunakan Unblocking Organizational Questionnaire (UOQ) oleh Francis \& Woodcock. Model ini memiliki 14 hambatan dalam organisasi (tujuan tidak jelas, nilai-nilai organisasi tidak jelas, filosofi manajemen tidak layak, kurangnya pengembangan manajemen, struktur organisasi yang tidak jelas, kontrol organisasi yang tidak memadai, perekrutan dan seleksi yang tidak tepat, imbalan tidak adil, pelatihan yang kurang, kurangnya pengembangan pribadi, komunikasi yang tidak berjalan lancar, kerja tim yang buruk, motivasi rendah, dan kreativitas rendah). Dalam 
mengumpulkan data, sampel yang digunakan adalah 28 orang dengan membagikan kuesioner. Dalam hasil penelitian ini ditemukan bahwa Bank "X" saat ini menerapkan budaya adhokrasi. Namun, pada lima tahun ke depan mereka mengharapkan memiliki kombinasi budaya yang berbeda yaitu budaya pasar dan klan. Alternatif dimensi budaya pasar menjadi fokus utama dalam lima tahun ke depan untuk meningkatkan pencapaian target. Gambar profil budaya ini dapat digunakan sebagai masukan bagi perusahaan untuk pembuatan kebijakan untuk menciptakan budaya organisasi yang kompatibel dengan visi dan misi perusahaan. Dan untuk hasil hambatan organisasi dalam pemanfaatan sumber daya manusia di Bank " $X$ " adalah pelatihan yang buruk, imbalan yang tidak adil, dan kreativitas yang rendah.

Kata kunci: Budaya Organisasi; Hambatan Organisasi, Organization Culture Assesment Instrument (OCAI), Unblocking Organizational Questionnaire (UOQ)

\section{PENDAHULUAN}

Organisasi maupun perusahaan tidak akan lepas dari manajemen sumber daya manusia. Budaya organisasi dapat didefinisikan sebagai sebuah kesatuan dari orang-orang yang memiliki tujuan, keyakinan, dan nilai yang sama. Pada dasarnya setiap organisasi menginginkan terciptanya visi dan misi yang membudaya pada setiap anggota organisasinya. Seluruh anggota organisasi di dalamnya diwajibkan untuk paham dan menjadikan corporate value sebagai landasan dalam bertindak dan menyelesaikan berbagai macam persoalan yang ada, serta mendukung terwujudnya visi dan misi organisasi.

Mengelola organisasi bukanlah hal yang mudah. Banyak hambatan dan dilema yang akan dihadapi dalam mewujudkan organisasi yang efektif dan produktif. Terlebih dalam hal mengelola manusia di dalam organisasi. Manusia dan cara mengelola sumber daya manusia dalam perusahaan menjadi makin penting karena semakin banyak sumber daya lain menjadi kurang keampuhannya untuk dapat tetap bersaing dalam dunianya. Keberadaan manajemen sumber daya manusia dalam suatu perusahaan bertujuan untuk meningkatkan kontribusi karyawan terhadap organisasi dalam rangka mencapai tujuan organisasi. Hal ini dapat dipahami karena semua kegiatan organisasi dalam pencapaian tujuannya bergantung kepada manusia yang mengelola organisasi perusahaan. Hanya organisasi yang memiliki sumber daya manusia yang berkualitas yang akan mampu memenangkan persaingan dan dapat mengembangkan organisasi.

Mengatur suatu organisasi bukanlah perkara yang mudah. Banyaknya tantangan dan hambatan yang akan dialami dalam menciptakan sebuah organisasi yang efektif dan efisien. Terutama pengelolaan manusia dalam organisasi. Pengelolaan sumber daya manusia harus menjadi fokus yang utama dikarenakan sumber daya yang lainnya tidak mampu bertahan dalam persaingan. Dengan adanya manajemen sumber manusia dalam organisasi diharapkan dapat meningkatkan kontribusi anggota dalam mencapai tujuan organisasi. Selain itu tercapainya tujuan organisasi bergantung pula terhadap manusia yang mengelola organisasi tersebut. Karena hanya organisasi yang memiliki sumber daya manusia yang berkualitas yang akan mampu bersaing dan mampu mengembangkan organisasinya.

Sama halnya dengan Bank " $X$ " yang merupakan bank dalam grup Buku 1 (modal kurang dari 1 triliun). Kepemilikan bank ini merupakan sebuah bank yang dimiliki secara perorangan di mana pemiliknya masih sangat dominan dalam setiap pengambilan keputusan perbankan. Tetapi pada tahun 2015 Bank "X" ini memutuskan untuk go public. Dengan menjadi Tbk. tentu saja bukan hal yang mudah bagi pemilik dan karyawannya, di mana kinerja para karyawan harus semakin ditingkatkan karena akan mempengaruhi pada hal-hal seperti adanya investor yang akan membeli saham dan akan memengaruhi secara langsung modal yang diterima. Karena hal ini maka pihak bank menuntut para karyawan supaya bekerja keras dan harus mencapai target-target yang sudah ditentukan. Dan dengan kata lain maka Bank "X" harus bekerja semaksimal mungkin untuk bersaing dengan bank-bank lainnya.

Persainganpun tidak dapat dihindari lagi, perusahaan harus menjadi lebih sensitif terhadap permintaan pasar, budaya organisasi, dan juga hambatan yang dihadapi organisasi. Budaya organisasi memiliki peran penting dalam perusahaan karena dapat digunakan sebagai pesaing utama dalam organisasi dan dapat menjawab tantangan dan perubahan. Budaya organisasi juga berfungsi sebagai 
pengikat dalam proses menyamakan persepsi atau arah pandangan seorang anggota terhadap suatu masalah, sehingga akan menjadi kekuatan dalam pencapaian tujuan organisasi (Rosidah \& Gustomo, 2014). Peran budaya dalam memengaruhi perilaku karyawan tampaknya semakin penting di tempat kerja saat ini. Budaya meningkatkan komitmen organisasi dan meningkatkan konsistensi perilaku karyawan. Di setiap perusahaan memiliki budaya organisasi yang berbeda dan hambatan-hambatan yang dihadapi oleh organisasipun akan berbeda pula.

Dengan adanya dasar pertimbangan-pertimbangan di atas, maka penelitian mengenai budaya perusahaan saat ini dan masa yang akan datang serta hal-hal yang menghambat perusahaan perlu dilakukan untuk memanfaatkan sumber daya manusia yang dimiliki demi mencapai efektivitas dan efisiensi organisasinya.

\section{Budaya organisasi}

Budaya adalah sumber daya strategis dengan nilai dalam memastikan keberlanjutan eksistensi dan keberhasilan organisasi (Simamora, Jerry, \& Hartono, 2016). Budaya organisasi adalah pola asumsi dasar bersama yang dipelajari kelompok ketika memecahkan masalah adaptasi eksternal dan integrasi internal yang telah bekerja dengan cukup baik untuk dianggap valid dan, oleh karena itu, untuk diajarkan kepada anggota baru sebagai cara yang tepat untuk melihat, berpikir, dan rasakan sehubungan dengan masalah itu (Rosidah \& Gustomo, 2014).

Tjahjono (2010) menjelaskan bahwa sebuah budaya organisasi pada dasarnya harus diajarkan, dipelajari, dikembangkan, disosialisasikan, diinternalisasikan, serta dijadikan pedoman melalui nilainilai yang ada. Sehingga budaya organisasi tidak mutlak bersifat warisan sebab jika benar demikian maka proses transformasi tidak akan terjadi. Perlu disadari bahwa transformasi budaya (culture change) akan tampak mendasar. Transformasi budaya ini akan menjadi suatu proses reorganisasi dan revitalisasi nilai-nilai, yang pada gilirannya akan memengaruhi sikap (attitude), norma-norma perilaku (behavioral norms), gaya manajemen (management styles), serta sistem (system) (Tjahjono, 2010).

Tjahjono (2010) menjelaskan bahwa budaya organisasi itu harus disosialisasikan terus menerus karena anggota selalu berganti sehingga budaya harus selalu diberitahukan tanpa lelah kepada anggota yang baru. Selain itu budaya harus dijadikan sebagai nilai-nilai untuk bertindak dan budaya pun dapat memengaruhi perilaku anggota dalam suatu organisasi. Fungsi budaya organisasi menurut Luthans (2008); dalam Tanadi (2014) yaitu:

1. Keteraturan perilaku yang dijalankan

2. Norma, standar perilaku

3. Nilai yang dominan pendukung organisasi

4. Filosofi yang ditetapkan dalam perusahaan

5. Aturan yang tidak boleh dilakukan oleh anggota organisasi

6. Iklim organisasi tercermin dari cara berinteraksi antar anggota organisasi

\section{Model competing values}

Untuk mengidentifikasi budaya suatu organisasi tentu bukanlah hal yang mudah. Hal ini disebabkan karena budaya mempunyai komponen tak berwujud yang justru menjadi inti dari budaya organisasi itu sendiri (Schein, 2004). Oleh karena itu Cameron \& Quinn (1999); Febriana \& Yuniawan (2013) mengembangkan Competing Value Framework (CVF) yang diharapkan dapat membantu para peneliti dalam mengidentifikasi budaya organisasi suatu perusahaan.

Model competing values merupakan salah satu model yang cukup komprehensif dalam menjelaskan hubungan kultur terhadap berbagai aspek organisasi. Model ini memperlihatkan secara terperinci bahwa setiap tipe budaya memiliki kecenderungan yang berbeda dalam sejumlah variabel organisasi yang dipengaruhnya (Kusdi, 2011; Kusumaningtyas \& Darmastuti, 2016).

Model competing values dibangun oleh Quinn dan Cameron yang dikelompokkan menjadi dua dimensi, yang terdiri dari empat kuadran. Dimensi pertama adalah kriteria-kriteria efektivitas yang menekankan kepada fleksibilitas, keleluasaan (discresion), dan dinamika atau lebih menekankan stabilitas, keteraturan, dan kontrol. Dimensi kedua membedakan kriteria-kriteria efektivitas yang menekankan orientasi eksternal, integrasi, dan kesatuan atau lebih menekankan orientasi eksternal, diferensiasi, dan persaingan (rivalitas). Dua dimensi ini secara bersamaan membentuk empat kuadran dengan menggambarkan suatu perangkat yang berbeda/nyata dari indikator/faktor keefektifan organisasi. Kedua dimensi tersebut merupakan indikator keefektifan organisasi. Indikator keefektifan 
tersebut menggambarkan mengenai nilai para personil tentang kinerja organisasi. Mereka mengidentifikasikan apa yang terlihat sebagai hal yang baik dan benar serta memadai menurut pandangannya. Setiap kuadran menggambarkan anggapan dasar (basic assumption), orientasi, dan tata nilai yang mencirikan elemen atau jenis budaya organisasi.

Dua dimensi budaya tersebut membentuk empat kuadran budaya yang disebut juga sebagai jenis budaya yang mejelaskan pula nilai inti yang dirasakan atau dikehendaki dan diyakini yang dapat mempengaruhi keefektifan organisasi dan kinerja sesuai dengan tantangan perubahan lingkungan (Cameron \& Quinn, 1999; Febriana \& Yuniawan, 2013) yaitu:

1. Clan culture

Model atau jenis budaya yang menekankan pada keakraban dan ikatan emosi untuk saling berbagi, sehingga organisasi lebih tampak seperti keluarga yang saling menaungi satu sama lain. Setiap anggota memiliki rasa kebersamaan dan kekeluargaan. Nilai yang diutamakan oleh kultur ini adalah teamwork. Sedangkan pedoman manajemen yang dipakai biasanya berprinsip pada pentingnya partisipasi karyawan atau anggota organisasi. Komitmen karyawan atau kelompok dicapai melalui pengembangan partisipasi karyawan dalam dinamika kerja, proses manajemen, berusaha mencapai mufakat, serta pengambilan keputusan.Organisasi diikat oleh loyalitas dan tradisi, pemimpin di dalam kultur ini lebih berfungsi sebagai mentor dengan sifat otoriter dan memungkinkan seluruh tim bekerja atas nama kelompok dengan mengesampingkan penonjolan individu.

2. Adhocracy culture

Model atau jenis budaya yang sangat dinamis, dijiwai semangat entrepreneurship, energi dan kreativitas. Nilai yang sangat diutamakan adalah inovasi, berpikir di luar kebiasaan untuk menyelesaikan sesuatu, dan keberanian mengambil resiko. Gaya kepemimpinan yang dikembangkan lebih sebagai innovator, wirausaha, serta visionary leadership. Ikatan yang menyatukan organisasi adalah komitmen terhadap eksperimen dan inovasi. Kesuksesan sebuah kerja organisasi diukur oleh penemuan produk/jasa baru yang inovatif.

3. Market culture

Model atau jenis budaya ini beroperasi pada mekanisme ekonomi pasar, dengan melakukan transaksi-transaksi yang ditujukan untuk menciptakan keunggulan kompetitif dan pencapaian hasil yang nyata. Organisasi tipe kebudayaan pasar ini berpusat pada lingkungan ekternal yaitu pelanggannya. Konsep penting di dalam kultur ini adalah transaction cost. Jadi organisasi lebih berorientasi tehadap hasil, bukan proses. Gaya kepemimpinan yang dikembangkan adalah sebagai competitor dan pendorong yang tangguh. Tujuan jangka panjang dari kultur ini adalah melakukan aktivitas yang kompetitif dan pencapai sasaran yang sudah ditargetkan, sukses dilihat dari pangsa pasar dan penguasaan pasar.

4. Hierarchy culture

Model atau jenis budaya yang sangat formal dan teratur, di mana setiap aktivitas semua lini manajemen mempunyai sebuah aturan main yang jelas, sesuai dengan apa yang dikehendaki organisasi. Segala sesuatu, mulai dari penentuan kebijakan, pencapaian target strategis didasarkan pada prosedur. Gaya kepemimpinan yang dikembangkan adalah sebagai kordinator dengan fungsi mentoringnya yang kuat dan ketat, sekaligus juga sebagai organisator yang unggul. Organisasi diikat oleh aturan-aturan dan kebijakan formal, dan nilai yang dianggap paling penting adalah efisiensi dan kelancaran jalannya organisasi. Model atau pedoman manajemen yang digunakan biasanya berpusat pada pengendalian dan kontrol yang ketat. Sukses diukur dari produk yang bisa diandalkan, penghematan biaya, dan tentunya kelancaran jadwal.

Organizational Culture Assessment Instrument (OCAI)

Cameron \& Quinn (1999); Sobirin (2007); Kusumaningtyas \& Darmastuti (2016) juga bisa disebut sebagai penerus konsepnya Harisson. Namun berbeda dengan penerus sebelumnya Cameron \& Quinn menggunakan kriteria yang berbeda yaitu "Competing Values Framework" untuk menetapkan keempat budaya yang berbeda dan menggunakan Organizational Culture Assessment Instrument (OCAI) sebagai instrumennya.

Pada saat melakukan pengumpulan data, penelitian ini menggunakan satu kuesioner yaitu kuesioner OCAI (Organizational Culture Assesment Instrument). Kuesioner tersebut dapat mengetahui enam dimensi dalam budaya organisasi (Cameron \& Quinn, 2011), seperti: karakteristik dominan (dominant organizational characteristics); kepemimpinan oerganisasi (organizational leadership); pengelolaan 
karyawan (management of employees); perekat organisasi (organizational glue); penekanan strategis (strategic emphasis); kriteria sukses (criteria of success).

\section{Hambatan organisasi}

Dalam sebuah organisasi tidak akan mungkin selalu berjalan mulus, tentu banyak faktor yang dapat memengaruhi dalam pencapaian tujuan organisasi tersebut. Yang menjadi fokus utama dalam pencapaian tujuan suatu organisasi dan yang memberikan kontribusi langsung bagi keberhasilan organisasi adalah perilaku manusia di dalam organisasi tersebut. Maka dalam penelitian ini sumber daya manusia dianggap ujung tombak dalam organisasi, karena sumber daya manusia lah yang dapat beradaptasi dengan situasi yang baru.

Menjadi hal yang penting untuk mengetahui bagaimana pandangan pegawai mengenai hambatan (blockage) dalam organisasi dalam mengelola sumber daya manusia yang dimilikinya, hal tersebut dapat mempengaruhi cara pandang terhadap organisasi dan akan mempengaruhi perilaku kerjanya.

Teori dasar diambil berdasarkan penelitian Francis \& Woodcock (1994); dalam Mangundjaya (2013) terhadap berbagai perusahaan mengenai hambatan organisasi dalam pengelolaan pegawainya. Berdasarkan penelitian itu maka terdapat 14 hambatan umum yang ada di dalam organisasi. Hambatanhambatan tersebut adalah:

1. Tujuan yang tidak jelas - Unclear aims. Jika suatu organisasi tidak memiliki pemahaman yang jelas tentang apa yang ingin dicapai dalam waktu tertentu maka masa depan akan tidak jelas. Hanya dengan mengetahui apa yang ingin dicapai oleh organisasi, organisasi akan dapat memutuskan tindakan yang diperlukan untuk mewujudkannya. Dengan kata lain, organisasi dengan tujuan yang jelas akan memiliki konsep yang koheren tentang identitasnya.

2. Nilai-nilai yang tidak jelas - Unclear values. Nilai adalah kunci untuk kinerja organisasi. Nilai juga mendasari banyak masalah organisasi. Budaya organisasi didasarkan pada sistem nilai informal yang diekspresikan dalam perilaku. Dalam hal ini, budaya hanya dapat diubah ketika nilai-nilai didefinisikan ulang.

3. Filosofi manajemen yang tidak layak - Inappropriate management philosophy. Sebagian besar organisasi yang efektif menempatkan premi tinggi pada filosofi manajemen yang mendorong keterbukaan, probing, kejujuran, dan keinginan untuk menghadapi masalah serta bekerja secara konstruktif untuk menyelesaikannya. Akibatnya, ketika seorang manajer mencoba untuk bekerja secara konstruktif pada masalah, orang-orang jauh lebih mungkin untuk membesarkan masalah dan ide mereka sendiri dengannya, sehingga memaksimalkan kontribusi semua orang. Cara kerja ini menawarkan prospek terbaik dalam menggunakan potensi tersembunyi dari orang-orang. Di sisi lain, ketika seorang manajer menghindari masalah, dan terus menyapu masalah di bawah karpet, masalah itu menjadi lebih besar.

4. Kurangnya perencanaan dan pengembangan manajemen - Lack of management development. Organisasi yang telah berhasil secara konsisten selama bertahun-tahun selalu memberikan perhatian pada dua hal: mempersiapkan masa depan dan mengembangkan kemampuan masingmasing individu. Banyak organisasi yang tersandung oleh masalah pengembangan manajemen mereka. Meskipun terlalu banyak perencanaan dapat menimbulkan masalah, penting untuk menentukan derajat yang relevan.

5. Struktur organisasi yang membingungkan - Confused organizational structure. Tidak peduli bagaimana bisnis diatur. Orang mungkin akan mengeluh bahwa efek totalnya membuat frustrasi dan sering kali tidak efisien. Namun, terlepas dari semua kesulitan, organisasi adalah fitur yang diperlukan dari masyarakat kita. Mereka adalah teman kami, dan kami perlu mengetahui kekuatan dan kelemahan mereka dan belajar bagaimana membuat mereka melayani kami. Organisasi harus sesuai dengan kebutuhan bisnis, bukan sebaliknya. Setiap kali orang-orang dikelompokkan bersama, ada masalah-masalah koordinasi yang tak terelakkan. Ketika perusahaan tumbuh dalam ukuran, pertanyaan tentang organisasi menjadi lebih terlibat dan lebih penting - yang menuntut pemikiran yang cermat; jika tidak, kesulitan untuk menyelesaikan sesuatu menjadi begitu besar sehingga orang-orang akan menyerah untuk mencoba dan hanya berkonsentrasi untuk menghindari masalah.

6. Kontrol yang tidak memadai - Inadequate control. Tanpa kontrol yang memadai, hal ini dapat terjadi di perusahaan yang walaupun bagian dari perusahaan berjalan dengan baik, namun yang lain merusak gambar, dan manajemen tidak tahu fungsi mana yang menyebabkan masalah, dan dapat 
juga terjadi bahwa neraca untuk tahun keuangan sebelumnya menunjukkan laba yang sangat baik, tetapi laba mengkhawatirkan manajemen, karena itu benar-benar mengejutkan, dan itu tidak akan lebih mengherankan jika untung itu rugi. Kedua situasi ini adalah contoh dari kontrol yang tidak memadai.

7. Rekrutmen dan seleksi yang tidak tepat - Inadequate recruitment and selection. Tim manajemen mengakui bahwa aset terbesar perusahaan adalah bakat dan keterampilan kreatif dari departemen penelitian dan pengembangannya. Karena dipahami bahwa karena pekerjaan itu penting bagi kesejahteraan perusahaan, manajemen harus menangani kegiatan rekrutmen dan seleksi secara serius.

8. Imbalan yang tidak adil - Unfair rewards. Organisasi membutuhkan orang dan orang-orang membutuhkan organisasi. Pada umumnya, orang-orang terbaik cenderung pergi ke organisasi yang menawarkan hadiah terbaik. Sebaliknya, organisasi yang membayar di bawah standar cenderung merekrut karyawan yang tidak memadai. Uang adalah subjek emosional karena posisi keuangan seseorang dalam masyarakat merupakan tolok ukur keberhasilan yang penting. Suka atau tidak suka, pemberi kerja membuat keputusan nyata tentang nilai kita, dari mana banyak konsekuensi memengaruhi dan memengaruhi seluruh gaya hidup kita, jenis rumah yang kita tinggali, jenis mobil yang kita kendarai, dan bahkan peluang pendidikan bagi anak-anak kita. Kadang-kadang orang menilai kita dengan gaji dan tingkat status dan sering mengukur keberhasilan dengan kecepatan di mana kita naik ke puncak piramida.

9. Training yang kurang - Poor training. Kadang-kadang sulit untuk membayangkan bahwa ada caracara belajar yang lebih baik daripada metode in dari magangnya. Untungnya, orang memutuskan untuk mencoba beberapa teknik pelatihan sistematis yang dianjurkan oleh spesialis. Banyak orang terkejut, dia menemukan bahwa instruksi yang cermat mengurangi waktu belajar.

10. Kurangnya pengembangan diri - Lack of personal development. Organisasi ada untuk dicapai. Mereka mengumpulkan keterampilan dan pengetahuan individu dan menciptakan lingkungan yang dapat membawa kesuksesan dan pencapaian. Terkadang organisasi membantu orang untuk berkembang, tumbuh lebih kuat, dan menjadi lebih cakap, tetapi sebaliknya juga terjadi. Organisasi menghambat perkembangan individu yang menyebabkan orang menjadi stagnan alih-alih tumbuh. Ketika diarahkan menuju tujuan organisasi, kekuatan dan kemampuan individu menyediakan sumber daya nilai yang luar biasa: vitalitas kreatif untuk menyelesaikan masalah dan untuk terus beradaptasi dan berkembang.

11. Komunikasi tidak berjalan lancar - Inadequate communication. Perusahaan besar pernah menolak. Pemotongan biaya manajemen yang tidak sehat dan otoriter, menolak untuk berinvestasi di masa depan dan tenaga kerja menjadi semakin kecewa. Kemudian manajemen baru datang, meninjau strategi perusahaan dan memutuskan perubahan yang diperlukan. Ini diumumkan kepada semua karyawan oleh seorang kepala eksekutif yang agak introvert. Dia mengharapkan sambutan yang meriah tetapi disambut dengan ketidakpercayaan dan sinisme. Apa dasar masalahnya? Strategi baru didirikan dengan baik. Manfaat akan mengalir ke semua. Perusahaan akan tumbuh lagi. Namun, tidak satupun dari kebenaran ini diterima oleh tenaga kerja. Mereka hanya mengingat janji-janji yang tidak menentu dan sikap-sikap mencela dari manajemen sebelumnya. Pada titik ini, organisasi menderita karena komunikasi yang tidak memadai.

12. Kerja tim yang tidak berjalan lancar - Poor teamwork. Organisasi ada untuk melakukan tugas-tugas kompleks yang tidak dapat ditangani oleh seorang individu. Bekerja bersama dalam kelompok adalah hal yang menyenangkan dan memuaskan bagi sebagian besar orang. Bersama-sama, sebuah tim dapat mencapai lebih dari upaya individu total dari anggotanya sendiri. Ketika sebuah tim dipimpin dengan baik dan memenuhi kebutuhan anggotanya, ia menyalurkan energi besar ke dalam kerja yang efektif. Di sisi lain, tim yang dipimpin dengan buruk yang membuat frustrasi anggotanya mengeluarkan banyak energi produktif yang menggerutu dan membalas. Orang-orang pada umumnya akan cepat mengenali kerja tim yang buruk, seperti pekerjaan yang tidak pernah dilakukan dengan benar, dan pertengkaran dan kelesuan berkembang di antara rekan setim.

13. Motivasi Rendah - Low motivation. Para jenderal tentara yang sukses, manajer tim sepak bola, guru sekolah, dan pemimpin politik, semua memahami pentingnya orang-orang berkomitmen terhadap tugas yang ada di tangan. Kemampuan untuk melakukan pekerjaan tertentu adalah satu hal, tetapi ingin melakukannya adalah hal lain. Sejarah penuh dengan situasi di mana orang telah berhasil mencapai tujuan tertentu, meskipun peluang hampir mustahil, ketika mereka benar-benar ingin. 
Meskipun berbagai jenis kepemimpinan relevan untuk menyelesaikan berbagai tugas, terutama yang penting adalah kemampuan untuk menemukan kunci yang tepat untuk membuka kunci energi laten pada orang dan untuk memanfaatkannya pada tugas yang ada.

14. Rendahnya kreatifitas - Low creativity. Organisasi dan individu hidup dalam dunia fluktuasi konstan yang berasal dari berbagai sumber: politik, masyarakat, pendidikan, teknologi, dan lainlain. Berdasarkan itu, setiap organisasi yang ingin bertahan dan tumbuh perlu mengikuti tren dan perubahan ini.

\section{METODE PENELITIAN}

Metode penelitian yang digunakan adalah metode deskriptif yaitu suatu metode yang bertujuan untuk menerangkan keadaan yang sebenarnya dari variabel yang akan diteliti. Penelitian deskriptif pada umumnya dilakukan untuk menggambarkan secara sistematis fakta dan karakteristik subjek dan objek penelitian. Sekaran (2010) mendefinisikan penelitian deskriptif sebagai berikut: "A descriptive study is undertaken in order to ascertain and be able to describe the characteristics of variables of interest in situations. Descriptive study is also undertaken to understand the characteristics of the organization that follows certain common practices". Penelitian ini menggunakan jenis penelitian dengan pendekatan kuantitatif yaitu dengan menggunakan kuesioner. Dalam mengolah dan menganalisis data, penelitian ini menggunakan salah satu instrumen yaitu Organization Culture Assessment Instrument (OCAI). OCAI adalah salah satu instrumen yang digunakan untuk mengidentifikasi budaya dalam suatu organisasi. Instrumen OCAI terdiri dari 6 (enam) pertanyaan, di mana disetiap pertanyaan terdapat 4 (empat) alternatif jawaban. Masing-masing responden diminta untuk memberikan penilaian pada setiap alternatif jawaban. Pemberian nilai tertinggi diberikan untuk alternatif jawaban yang dirasa paling mirip dengan keadaan organisasi saat ini tempatnya bekerja. Untuk menentukan organisasi mana yang akan diberi penilaian, setiap responden memikirkan organisasi yang dipimpin oleh pimpinannnya atau unit organisasi tempatnya bekerja yang memiliki batasan-batasan yang jelas. Dalam lembar kuesioner yang disediakan, responden diminta untuk memberikan skor pada setiap dimensi budaya yang ada berdasarkan kondisi yang dirasakan saat ini dan kondisi yang diharapkan pada lima tahun yang akan datang.

Kuesioner mengenai hambatan organisasi dalam mengelola sumber daya manusia yang dimilikinya dan disusun berdasarkan hasil adaptasi dari Unblocking Organizational Questionnaire (UOQ) yang dikembangkan oleh (Francis \& Woodcock, 1994). Teori yang digunakan untuk mengembangkan kuesioner ini mengacu pada hambatan-hambatan (blockages) umum yang ditemui oleh organisasi berdasarkan hasil penelitian mereka sejak tahun 1964. Sistem ini dianalisa dengan menggunakan teori blockage dengan metode deskriptif untuk menganalisa faktor-faktor hambatan dan metode pembobotan untuk menghitung hasil kuesioner, di mana karyawan mengisi kuesioner dengan menjawab pernyataan dari 14 hambatan yang ada dan 3 hambatan yang mendapatkan skor tertinggi merupakan akar masalahnya.

Prosedur probability sampling digunakan pula dalam penelitian ini karena memberi kepercayaan lebih besar bahwa sampel cukup mewakili populasi. Untuk metoda probability sampling yang digunakan adalah sampel acak sederhana (simple random). Di dalam sampling random sederhana, masing-masing anggota populasi yang dikenali mempunyai kesempatan yang sama untuk terpilih. Berdasarkan ukuran sampel populasi tersebut maka ditentukan ukuran sampel penelitian dengan menggunakan rumus Siovian \& Sevilla (1994) sebagai berikut:

$$
n=\frac{N}{1+(N)\left(e^{2}\right)}
$$

Keterangan:

$\mathrm{n}=$ ukuran sampel minimal

$\mathrm{N}=$ ukuran populasi

$\mathrm{e}=$ tingkatan kesalahan yang ditolerir

Pada penelitian ini tingkat kesalahan yang ditolelir adalah 10\%. Jumlah populasi dari Bank "X" adalah 40 orang sehingga jumlah sampel minimal yaitu 28 orang. 
Jurnal Manajemen Maranatha a Vol. 19 Nomor 1, November (2019)

\section{HASIL DAN PEMBAHASAN}

Hasil penelitian budaya organisasi

Responden penelitian ini adalah perwakilan dari seluruh karyawan Bank "X" yang terdiri dari karyawan bagian operasional dan bisnis. Karakteristik responden dalam penelitian ini dikategorikan berdasarkan jabatan atau status, umur, pendidikan, lama bekerja dan jenis kelamin.

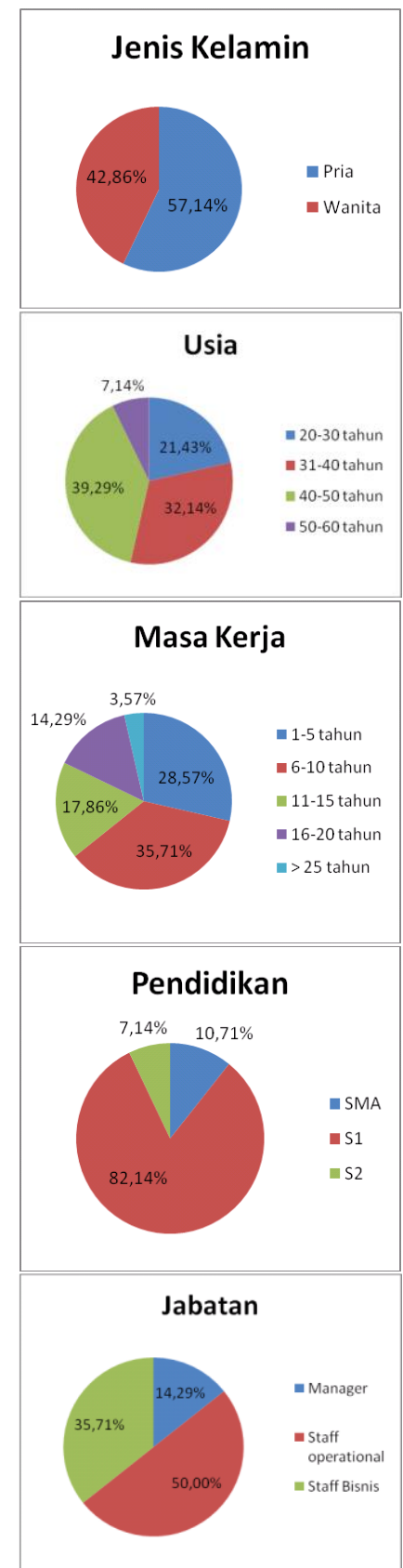

Dari hasil penilaian tipe budaya pada Organizational Culture Assesment Instrument di atas maka kemudian diperoleh skor dari masing-masing tipe budaya pada saat ini dan masa yang akan datang

Tabel 1. Persentase skor tipe budaya organisasi

\begin{tabular}{lcc}
\hline \multicolumn{1}{c}{ Budaya } & Now & Preferred \\
\hline Clan & $20 \%$ & $20,3 \%$ \\
Adhocracy & $33,3 \%$ & $32,2 \%$ \\
Market & $26,11 \%$ & $28,2 \%$ \\
Hierarcy & $20,5 \%$ & $19,4 \%$ \\
\hline
\end{tabular}


Sumber: Pengolahan data

Dari Tabel 1 di atas, selanjutnya digambarkan pemetaan atau mapping budaya organisasi yang ada pada saat ini di Bank "X" Bandung dan di masa yang akan datang sesuai dengan persepsi pegawainya. Berikut merupakan gambar pemetaan budaya organisasi pada Bank "X" Bandung.

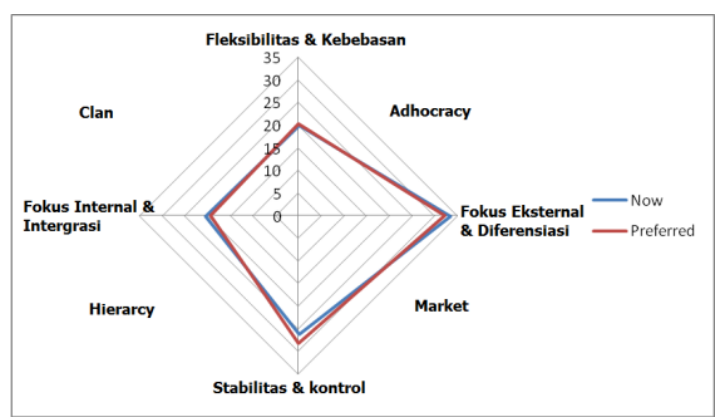

Gambar 1. Pemetaan budaya pada Bank "X"

Sumber: Pengolahan data

Dengan memerhatikan gambaran pemetaan budaya organisasi, skor tertinggi pada suatu kuadran mengindikasikan budaya yang dominan pada suatu organisasi (Cameron \& Quinn, 2011). Dari pemetaan budaya organisasi pada Bank "X" di atas dapat diketahui bahwa pada saat ini di antara empat budaya yang ada, jumlah persentase bisa dikatakan seimbang karena skor yang diperoleh relatif setara. Dapat dilihat pada Tabel 1 bahwa skor untuk clan culture sebesar 20\%, adhocracy culture sebesar 33,3\%, market culture sebesar 26,11\% dan hierarchy culture sebesar 20,5\%. Dari data tersebut budaya yang saat ini diterapkan oleh Bank "X" adalah adalah adhocracy culture, market culture dan hierarcy culture; tetapi budaya yang paling dominan adalah adhocracy culture. Namun di masa mendatang terjadi kenaikan skor untuk market culture dari $26,11 \%$ menjadi $28,2 \%$ dan clan culture dari $20,3 \%$ menjadi $20 \%$; sedangkan adhocracy culture mengalami penurunan skor dari 33,3\% menjadi 32,2\% dan hierarcy culture dari $20,5 \%$ menjadi $19,4 \%$. Sehingga dapat disimpulkan di masa mendatang budaya organisasi secara eksternal tetap dipertahankan dan untuk budaya internal para karyawan menginginkan adanya sedikit perubahan dari hierarcy culture menjadi clan culture tetapi budaya yang diharapkan paling dominan adalah market culture.

Dari hasil pemetaan budaya tersebut dapat diketahui bahwa saat ini secara keseluruhan budaya yang dirasakan yaitu adhocracy cultur; belum sesuai dengan visi, misi dan nilai-nilai pada Bank " $X$ " yang menekankan pada anggota organisasi tidak dibatasi oleh struktur, sebab lebih mementingkan penciptaan situasi di mana karyawan bisa bebas menggali serta menyalurkan ide yang segar, kreatif, dan inovatif serta berpandangan kedepan dan mandiri. Dengan melakukan inovasi secara terus menerus, diharapkan organisasi akan terus bertumbuh dan berkembang menjadi lebih baik.

Namun di masa mendatang karyawan menginginkan peralihan budaya yaitu adhocracy culture untuk berubah menjadi market culture yang lebih mementingkan efektivitas dalam bekerja, terfokus pada bagaimana menaklukan pesaing serta pencapaian target yang telah ditetapkan di awal. Karakteristik market culture adalah fokus pada hasil yang diperoleh, yaitu dengan mengevaluasi apakah pekerjaan yang dihasilkan sesuai dengan target yang sudah ditetapkan diawal. Pemimpin akan menjadi motivator yang sangat berperan penting dalam memberikan pengarahan kepada pegawai. Dalam menghadapi persaingan, reputasi perusahaan dan kesuksesan dalam jangka panjang merupakan hal yang paling utama.

Hasil penelitian hambatan organisasi

Berdasarkan hasil penelitian terhadap Bank " $X$ ", maka diperoleh data mengenai hambatan umum dalam pengelolaan pegawai dalam perusahaan. Keempat belas aspek hambatan ini kemudian diranking dari aspek yang dianggap hambatan paling utama sebagai ranking satu dan hambatan yang paling tidak mengganggu menjadi ranking empat belas. Hasilnya adalah sebagai berikut:

Tabel 2. Hambatan organisasi

\begin{tabular}{lll}
\hline Ranking & Aspek Hambatan & Point \\
\hline
\end{tabular}


Jurnal Manajemen Maranatha ø Vol. 19 Nomor 1, November (2019)

\begin{tabular}{clc}
\hline 1 & Poor training & 10 \\
2 & Unfair rewards & 7 \\
3 & Low creativity & 7 \\
4 & Inadequate control & 6 \\
5 & Confused organizational structure & 5 \\
6 & Low motivation & 4 \\
7 & Inappropriate management philosophy & 3 \\
8 & Inadequate recruitment and selection & 3 \\
9 & Lack of succession planning and management development & 2 \\
10 & Personnel stagnation & 2 \\
11 & Inadequate communication & 1 \\
12 & Poor teamwork & 1 \\
13 & Unclear aims & 0 \\
14 & Unclear value & 0 \\
\hline
\end{tabular}

Sumber: Pengolahan data

Dari data di atas, dapat disimpulkan bahwa terdapat tiga hambatan umum yang menjadi hambatan bagi organisasi dalam pengelolaan sumber daya manusianya. Ketiga hambatan tersebut adalah:

1. Poor training

2. Unfair rewards

3. Low creativity

Ketiganya diperoleh dari tiga hambatan yang mempunyai ranking tertinggi yang diberikan oleh subyek penelitian didasarkan pada Teori Blockages Organization oleh Woodcock \& Francis (1994).

\section{SIMPULAN DAN SARAN}

Simpulan

Berdasarkan hasil penelitian pada Bank "X", berikut ini kesimpulannya:

1. Profil budaya Bank " $X$ " yang saat ini dirasakan oleh para karyawan adalah adhocracy, market dan hierarcy culture di mana skor yang diperoleh relatif seimbang, dengan adhocracy culture sebagai budaya yang paling dominan dirasakan oleh karyawan. Budaya yang dirasakan adalah budaya yang berfokus pada lingkungan eksternal yaitu adhocracy culture dan market culture di mana budaya anggota organisasi tidak dibatasi oleh struktur, sebab lebih mementingkan penciptaan situasi di mana karyawan bisa bebas menggali serta menyalurkan ide yang segar, kreatif, dan inovatif serta berpandangan kedepan dan mandiri. Budaya yang paling dominan dirasakan adalah budaya adhocracy di mana mekanisme koordinasi dilakukan berdasarkan standardisasi kerja, kemampuan di mana setiap proses kerja berpedoman terhadap SOP (Standard Operation Procedure), namun juga tetap memasukan pertimbangan rasional ketika berhadapan dengan persoalan yang memang tidak tercantum panduannya di dalam SOP, di sinilah muncul adhokrasi. Dengan adanya SOP yang jelas pada Bank "X" menciptakan formalization of behaviour yang tinggi, terutama untuk unit operasional. Selain itu SOP juga sebagai panduan indoktrinasi bagi individu, untuk menjalankan perannya masing-masing, dalam mendukung kinerja setiap unit.

2. Profil budaya Bank " $X$ " yang diharapkan di masa mendatang adalah budaya yang berfokus pada lingkungan internal dan eksternal. Dengan market culture sebagai budaya yang dominan yang diinginkan oleh karyawan, di mana fokus utamanya adalah pegawai dapat menyelesaikan pekerjaan sesuai dengan terget yang telah dibuat di awal yang telah ditetapkan terlebih dahulu. Tujuan utama organisasi dengan menerapkan market culture adalah menjaga reputasi perusahaan, mencapai kesuksesan dan fokus untuk jangka panjang dalam menghadapi persaingan yang semakin ketat. Selain itu dikarenakan Bank "X" sudah go public, maka tuntutan untuk semakin memperbaiki kinerja semakin tinggi karena persainganpun semakin ketat, di mana kinerja bank akan memengaruhi para investor untuk menanamkan modalnya di bank ini.

3. Hambatan utama yang dihadapi oleh Bank "X" adalah training yang kurang, imbalan yang tidak adil, dan kreativitas rendah. Kurangnya training yang dilakukan kepada pihak karyawan menjadi hambatan bagi karyawan karena karyawan membutuhkan tambahan kemampuan (skill) untuk 
meningkatkan kinerja karyawan di dunia perbankan yang semakin melek terhadap teknologi. Di bank "X" ini, untuk karyawan baru biasanya mereka lebih menggunakan sistem learning by doing dari rekan sekerja mereka. Tetapi sebetulnya training sangat diperlukan terutama mengenai sistem dan prosedur dalam mendukung pelaksanaan kinerja karyawan. Untuk imbalan yang tidak adil dikarenakan bank ini merupakan bank dalam skala kecil bila dibandingkan dengan bank-bank lainnya, maka pihak bank kurang memberikan penghargaan bagi karyawan yang dapat menyebabkan demotivasi. Selain itu kurangnya kreativitas pun menjadi hambatan yang dirasakan oleh karyawan Bank "X". Hal ini dikarenakan dalam perbankan harus bekerja sesuai dengan SOP dan menaati semua peraturan pemerintah dan Bank Indonesia sehingga kreativitas akan terbatasi. Terutama dalam bidang operasional, kebanyakan karyawan hanya mengerjakan pekerjaan yang sama/stagnan yang mengakibatkan adanya kejenuhan dari karyawan sehingga membuat karyawan tidak dapat mengembangkan kemampuannya dan selanjutnya akan berada di zona nyaman.

Saran

Saran bagi penelitian yang akan datang mengenai budaya organisasi adalah dengan melakukan penelitian pendekatan kualitatif, di mana peneliti dapat memperdalam informasi yang diperoleh mengenai budaya di Bank " $X$ " tersebut. Berikut ini saran yang dapat digunakan oleh organisasi untuk pengambilan kebijakan dalam organisasi di antaranya:

1. Adhocracy culture dan market culture dirasa merupakan budaya organisasi yang diterapkan oleh Bank "X". Namun budaya clan harus tetap dijalankan untuk dijadikan sebagai landasan dan fondasi di dalam mencapai visi, misi, dan nilai-nilai perusahaan tersebut. Oleh karena itu setiap individu di perusahaan diharapkan untuk menginternalisasikan dan mengimplementasikan budaya yang menjadi landasan atau fondasi tersebut untuk mencapai tujuan perusahaan yang sesuai dengan adhocracy culture dan market culture agar bisa berjalan secara berkesinambungan dan berjalan dengan baik.

2. Mensosialisasikan hasil penelitian mengenai analisis budaya organisasi kepada seluruh karyawan. Tahap sosialisai ini akan dijelaskan mengenai kondisi dari budaya Bank "X" untuk saat ini dan harapan di lima tahun mendatang mengenai budaya yang ingin diterapkan oleh organisasi secara mendalam. Pada ajang ini pula dapat dijadikan juga sebagai media untuk berdiskusi mengenai harapan budaya yang ingin dicapai supaya semua yang ada di dalam organisasi mengerti dan paham mengenai budaya yang ingin dituju. Dengan harapan apabila seluruh pegawai mengetahui tujuan perusahaan maka dapat berjalan bersama untuk mencapainya.

3. Komunikasi antara manajemen atas, menengah, dan bawah mengenai visi, misi, dan nilai-nilai perusahaan harus diintensifkan. Sebab adanya perbedaan budaya yang diharapkan juga mengindikasikan karyawan memiliki pandangan baru yang bisa saja baik untuk perusahaan.

4. Menciptakan komunikasi antara atasan dan bawahan. Dengan adanya komunikasi yang baik antara atasan dan bawahan maka dapat mempermudah dalam pengambilan keputusan, proses transformasi budaya, dan keleluasaan pegawai untuk ikut berpartisipasi dalam pengambilan keputusan yang akan memicu karyawan lebih inovatif.

5. Karyawan baru maupun karyawan yang sudah lama bekerja di perusahaan sebaiknya diberikan pelatihan-pelatihan supaya meningkatkan keahlian mereka. Karena pelatihan ini berguna terutama mengenai sistem dan prosedur dalam mendukung pelaksanaan kinerja karyawan. Selain itu pelatihan ini juga akan mendukung peningkatan kinerja karyawan supaya dapat bersaing dengan bank yang lainnya dan mendapat kepercayaan dari investor untuk menanamkan modalnya di bank ini. Pelatihan yang saat ini sangat dibutuhkan adalah mengenai online banking, karena jaman sekarang ini semua orang sudah melek terhadap teknologi sehingga nasabah menuntut kemudahan-kemudahan dalam bertransaksi secara online.

6. Memberikan reward, contohnya dengan memberikan penghargaan (financial/non financial) kepada pegawai karena telah bekerja dengan efektif dan efisien sehingga memacu pegawai untuk bekerja lebih baik lagi dan memotivasi karyawan supaya bekerja dengan baik. Dengan memberikan penghargaan misalnya karyawan terbaik bulan ini diberikan uang atau voucher belanja, atau apresiasi dari atasan yang dapat diberikan kepada karyawan pada saat mencapai target.

7. Kreativitas yang rendah, terutama dalam bidang operasional kebanyakan karyawan hanya mengerjakan pekerjaan yang sama/stagnan yang mengakibatkan adanya kejenuhan dari karyawan sehingga membuat karyawan tidak dapat mengembangkan kemampuannya dan selanjutnya akan 
berada di zona nyaman. Maka dalam hal ini karyawan seharusnya diberikan kebebasan dalam berinovasi, asalkan sesuai dengan SOP dan peraturan-peraturan yang berlaku.

\section{REFERENSI}

Cameron, S. K., \& Quinn, E. R. (2011). Diagnozing and Changing Organizational Culture. San Fransisco: Jossey Bass

Febriana, Anggun Tri; Yuniawan, Ahyar. (2013). Analisis Pemetaan Budaya Organisasi Menggunakan OCAI pada PT Bank Pembangunan Daerah Jawa Tengah. Jurnal Studi Management \& Organisasi, 82

Francis, D., \& Woodcock, M. (1994). Unblocking Your Organization. A Revised and Expanded Edition of People at Work: A Practical Guide to Organizational Change. USA California: University Associates

Kusdi. (2011). Budaya Organisasi : Teori, Penelitian, dan Praktik. Jakarta: Salemba

Kusumaningtyas, Y., \& Darmastuti, I. (2016). Analisis Pemataan Budaya Organisasi Menggunakan OCAI pada Fakultas Ekonomika dan Bisnis Universitas Diponegoro. Jurnal Studi Management \& Organisasi, 57-66

Luthans, F. (2008). Organizational Behavior. Edisi XI. . New York: McGraw Hill

Mangundjaya, W. L. (2013). Diagnosing Indonesian organizations using Blockage Organization Inventory. Proceedings 5th International APIO Conference, 1-6

Rosidah, S., \& Gustomo, A. (2014). Analysis of Organisational culture and leadership style in RST Company. Journal of Business and management, 913-924

Schein, H. E. (2004). Organizational Culture and Leadership, 3rd Edition,. Jossey-Bass: A Wiley Imprint

Sekaran, U. (2010). Research Methods For Business. 5th edition. John Wiley \&Sons

Simamora, B., Jerry., \& Hartono, H. (2016). Strategy Alignment with OCAI Result of Cellular Industry in Indonesia. International Journal of Economics and Management, 81-93

Sobirin, A. (2009). Budaya Organisasi: Pengertian, Makna dan Aplikasinya dalam Kehidupan Organisasi. Yogyakarta: Unit Penerbit dan Percetakan Sekolah Tinggi

Tanadi, M. (2014). Pemetaan Budaya Organisasi di PT. Wisata Dewa Tour dan Travel tahun 2013. EJournal Graduate UNPAR, 45-68

Tjahjono, H. (2010). Culture Based Leadership : Menuju Kebesaran Diri \& Organisasi Melalui Kepemimpinan Berbasiskan Budaya dan Budaya Kinerja Tinggi. Jakarta: PT. Gramedia Pustaka Utama 